\title{
In situ determination of the moisture buffer potential of room enclosures
}

\author{
Vereecken, Evy; Roels, Staf; Janssen, Hans
}

Published in:

Journal of Building Physics

Link to article, DOI:

10.1177/1744259109358268

Publication date:

2011

Link back to DTU Orbit

Citation (APA):

Vereecken, E., Roels, S., \& Janssen, H. (2011). In situ determination of the moisture buffer potential of room enclosures. Journal of Building Physics, 34(3), 223-246. https://doi.org/10.1177/1744259109358268

\section{General rights}

Copyright and moral rights for the publications made accessible in the public portal are retained by the authors and/or other copyright owners and it is a condition of accessing publications that users recognise and abide by the legal requirements associated with these rights.

- Users may download and print one copy of any publication from the public portal for the purpose of private study or research.

- You may not further distribute the material or use it for any profit-making activity or commercial gain

- You may freely distribute the URL identifying the publication in the public portal

If you believe that this document breaches copyright please contact us providing details, and we will remove access to the work immediately and investigate your claim 


\title{
IN SITU DETERMINATION OF THE MOISTURE BUFFER POTENTIAL OF ROOM ENCLOSURES
}

\author{
EVY VEREECKEN ${ }^{1}$, STAF ROELS ${ }^{1}$ and HANS JANSSEN ${ }^{2}$ \\ ${ }^{1}$ Laboratory of Building Physics, Catholic University of Leuven \\ Kasteelpark Arenberg 40, B-3001 Leuven, Belgium \\ ${ }^{2}$ Department of Civil Engineering, Technical University of Denmark \\ Brovej - Building 118, 2800 Kgs. Lyngby, Denmark
}

\section{KEY WORDS:}

Moisture buffering, moisture buffer value, building energy simulation, effective capacitance model, effective moisture penetration depth model

\begin{abstract}
Indoor air quality, occupant's comfort, durability of building parts and energy consumption are highly related to the variations in indoor relative humidity. Since interior finishes and objects assist in dampening the peaks in relative humidity, the knowledge of the moisture buffer potential of room enclosures is necessary to include its effect in whole-building simulations.

In this paper, a method for the in situ determination of the moisture buffer potential of room enclosures is presented. During a period of some days, a humidifier is placed in a room and a moisture production scheme is implemented. Based on the measured $\mathrm{RH}$-increase and decrease during loading and unloading steps, the ventilation rate and moisture buffer potential of the room are determined inversely by solving the moisture balance of the room using the effective capacitance and effective moisture penetration depth models. The methodology is validated by well controlled experiments in a large climatic chamber with known hygric inertia, and afterwards applied to real room enclosures. Main advantage of the proposed method is that a simple and fast experiment allows obtaining a comprehensive characterisation of the hygric inertia of the whole building enclosure - including all interior finishes and multidimensional interior objects as furniture, carpets, drapes, books, etc.
\end{abstract}

\section{INTRODUCTION}

Indoor relative humidity plays a crucial role in realising a healthy indoor environment (Mudarri and Fisk, 2007), in the building occupants' thermal comfort and air quality perception (Fang et al., 1998; Toftum and Fanger, 1999), in the durability of building parts (Sedlbauer, 2002; Pasanen et al., 2000), and in the energy performance of building zones (Li et al, 2006; Osanyintola and Simonson, 2006; Pavlovas, 2004). Furthermore, paintings, wooden furniture etc. are often very sensitive to variations in relative humidity (Thomson, 1964). Therefore, besides the need for a precise control of the humidity in museums, due attention has to be paid to the humidity variations in office buildings, dwellings, schools, etc.

HVAC-installations can be used to reduce fluctuations in relative humidity. When dimensioning these installations, the moisture exchange with the room enclosure is usually simplified or neglected. Although, interior finishes (wooden floors, gypsum plasters,...) and interior objects (books, carpets, furniture,...) absorb or release moisture when exposed to a variation in relative humidity, and accordingly may yield a passive control of interior humidity. Measurements (Padfield, 1998; Simonson, 2004a; Svennberg, 2007; Kurnitski, 2007) and simulations (Kurnitski, 2007; Rode, 2004; Holm, 2004; Simonson, 2004b) have shown that such moisture ex- 
Postprint: Vereecken E, Roels S, Janssen H, 2011. In situ determination of the moisture buffer potential of room enclosures, Journal of Building Physics, 34(3): 223-246.

doi: $10.1177 / 1744259109358268$

change can have a serious influence on the interior humidity course. Consequently, taking the moisture buffering in the room enclosure into account permits a more accurate analysis of thermal comfort and air quality and of durability and sustainability. Its in depth treatment during the recently concluded IEA Annex 41 (Hens, 2008) also indicates its importance.

To account for interior moisture buffering, a dependable characterisation of the moisture buffer potential (MBP) of the entire room is needed first. Janssen and Roels (2009) demonstrated that such room MBP can be quantified by superposing the MBP's of the different interior elements. Although, the proposed standard MBV (Moisture Buffer Value) and HIR (Hygric Inertia of Room) proved good indicators of the moisture buffering effect only for moisture production schemes in close agreement with the imposed time intervals of the test protocol. To overcome this flaw, Janssen and Roels (2009) introduced a production-interval adapted $\mathrm{MBV}^{*}$ and a complementary production-interval adapted $\mathrm{HIR}^{*}$. They studied the validity of the proposed expression numerically, by simulating the dynamic response of a room covered with combinations of different finishing materials. An acceptably unique relationship between the dampening of the interior relative humidity variations and the $\mathrm{MBV}^{*} / \mathrm{HIR}^{*}$-value of the interior element/enclosure was found. Conclusively, Janssen and Roels (2009) demonstrated that the developed $\mathrm{MBV}^{*}$ and $\mathrm{HIR}^{*}$ not only form qualitative measures for the interior moisture buffering, but can also be applied for quantification of the moisture buffering effects on indoor humidity variations.

However, due to the diversity of interior finishes and interior objects such as furniture, books, carpets, etc., the determination of all single-element MBV*'s, to superpose to the room-enclosure $\mathrm{HIR}^{*}$, remains time-consuming and often unrealistic. Therefore, the current paper introduces the in situ determination of the hygric inertia of room enclosures, starting from the methodology developed in (Janssen and Roels, 2009).

An introductory section reiterates the general moisture balance equation for a building zone and its enclosure and the simplifying 'effective capacitance' and 'effective moisture penetration depth' models. The second and third sections present the characterisation of the singleelement $\mathrm{MBV}^{*}$ and room-enclosure $\mathrm{HIR}^{*}$ and their implementation in the simplified moisture balance. These sections form the basis for a method for the in situ determination of the buffering potential of room enclosures. The proposed method is validated by well-controlled experiments in a large climatic chamber with known hygric inertia. A practical example, in which the buffering potential of a real room is determined, concludes the paper.

\section{MOISTURE BALANCE FOR ROOM AIR AND ENCLOSURE}

To predict the evolution of interior vapour pressure, vapour concentration or dew point, the moisture balance equation for the room air is to be solved. Assuming ideal convective mixing and no surface condensation, supposing air exchange with the exterior environment only, and neglecting the temperature dependency of the air density, the moisture balance for the room air can be written as:

$$
\frac{V}{R_{v} T_{i}} \cdot \frac{\partial p_{v i}}{\partial t}=\left(p_{v e}-p_{v i}\right) \cdot \frac{n V}{3600 R_{v} T_{i}}+G_{v p}-G_{b u f}
$$

with $V\left(\mathrm{~m}^{3}\right)$ the volume of the room, $R_{V}(462 \mathrm{~J} /(\mathrm{kg} . \mathrm{K}))$ the gas constant for water vapour, $T_{i}$ $(\mathrm{K})$ the indoor air temperature, $V /\left(R_{v} T_{i}\right)\left(\mathrm{m}^{3} . \mathrm{kg} / \mathrm{J}\right)$ the moisture capacity of the zone air, $p_{v i / e}$ (Pa) the partial vapour pressure of indoor/outdoor air, $n(1 / \mathrm{h})$ the air change rate per hour, $G_{v p}(\mathrm{~kg} / \mathrm{s})$ the indoor vapour production and $G_{\text {buf }}(\mathrm{kg} / \mathrm{s})$ the moisture exchange between indoor air and all interior hygroscopic elements. The latter is commonly simplified, for which two models prevail: the effective capacitance model and the effective moisture penetration depth model.

\section{Effective moisture penetration depth model}

The effective moisture penetration depth (EMPD) model (Kerestecioglu et al., 1989; Cunningham, 2003) is a buffer storage model. The EMPD-model assumes that only a thin sur- 
Postprint: Vereecken E, Roels S, Janssen H, 2011. In situ determination of the moisture buffer potential of room enclosures, Journal of Building Physics, 34(3): 223-246.

doi: $10.1177 / 1744259109358268$

face layer $\left(d_{b}\right)$ of the interior finishes and objects contributes to the moisture buffering process. Moisture storage and transport in the buffering layer are described with a single-controlvolume equation. For a single buffer layer with available surface $A\left(\mathrm{~m}^{2}\right)$, the moisture exchange between indoor air and the humidity buffer layer is given by:

$$
G_{b u f}=A \cdot \frac{p_{v i}-p_{v b}}{\frac{1}{\beta}+\frac{d_{b}}{2 . \delta}}=A \cdot \xi \cdot d_{b} \frac{\partial}{\partial t}\left(\frac{p_{v b}}{p_{v, s a t}\left(T_{b}\right)}\right)
$$

with $p_{v b}(\mathrm{~Pa})$ the vapour pressure and $T_{b}(\mathrm{~K})$ the temperature, both in the centre of the humidity buffer layer with thickness $d_{b}(\mathrm{~m})$ and $\delta(\mathrm{s})$ and $\xi\left(\mathrm{kg} / \mathrm{m}^{3}\right)$ respectively the water vapour permeability and moisture capacity of the buffer layer.

\section{Effective capacitance model}

The effective capacitance (EC) model assumes that the buffer layer is always in hygric equilibrium with the interior air. This concept virtually moves the storage capacity of the room enclosure to the room air, and the buffer effect of hygroscopic materials is solved within the moisture balance of the room by correcting the moisture capacity of the indoor air:

$$
M \cdot \frac{V}{R_{v} T_{i}} \cdot \frac{\partial p_{v i}}{\partial t}=\left(p_{v e}-p_{v i}\right) \cdot \frac{n V}{3600 R_{v} T_{i}}+G_{v p}
$$

with $M$ an enlargement factor for the capacity of the zone air. Doing so makes the effective capacitance model a very easy method, since no extra equations have to be solved.

\section{ChARACTERISATION OF SINGLE-ELEMENT AND ROOM-ENCLOSURE MBP}

A dependable characterisation of single-element and room-enclosure MBP has already been introduced in (Janssen and Roels, 2009). For reasons of completeness, the crucial elements are repeated here.

\section{Single-element MBP characterisation}

As room enclosures usually consist of a variety of different interior finishes and objects, first a single-element MBP characterisation is required. Janssen and Roels (2009) show that cyclic step-change sorption/desorption measurements, as recommended by a Japanese Industrial Standard (JIS), a Draft International Standard (DIS) and a Nordtest protocol (NT), suit this aim best. Their suggested procedure combines the $8 / 16 \mathrm{~h}$ time intervals and $33 / 75 \% \mathrm{RH}$ humidity levels of the NT with the real sample thickness and the $2.10^{-8} \mathrm{~s} / \mathrm{m}$ surface mass transfer coefficient of JIS \& DIS. The Nordtest protocol defines the 'Moisture Buffer Value' (MBV) of a finish by a normalisation of the moisture mass amplitude per $\mathrm{m}^{2}$ open surface area and \% $\mathrm{RH}$ change:

$$
M B V_{8 h}=\frac{m_{\max }-m_{\min }}{A .\left(\phi_{\text {high }}-\phi_{\text {low }}\right)} \quad\left(\mathrm{kg} /\left(\mathrm{m}^{2} . \% R H\right)\right)
$$

where $m_{\max / \min }(\mathrm{kg})$ are the maximum/minimum moisture mass of the finish sample, $A\left(\mathrm{~m}^{2}\right)$ is the exposed surface of the sample, and $\phi_{\text {high/low }}(-)$ are the high/low $\mathrm{RH}$ levels applied in the measurement. An analogous definition for an object is:

$$
M B V_{8 h}^{\prime}=\frac{m_{\max }-m_{\min }}{\left(\phi_{\text {high }}-\phi_{\text {low }}\right)} \quad(\mathrm{kg} / \% R H)
$$

For the determination of the single-element MBV hence, the finish/object is placed in a small climatic chamber, where it is alternatingly exposed to $8 \mathrm{~h}$ at $75 \% \mathrm{RH}$ followed by $16 \mathrm{~h}$ at $33 \%$ $\mathrm{RH}$. Finishes will be sealed on all but the in reality exposed surfaces. At least three cycli should be carried out and the weight amplitude may not vary by more than $5 \%$ from day to day. Figure 1 shows the determination of the MBV for a bookshelf with books (Vereecken, 
Postprint: Vereecken E, Roels S, Janssen H, 2011. In situ determination of the moisture buffer potential of room enclosures, Journal of Building Physics, 34(3): 223-246.

doi: $10.1177 / 1744259109358268$

2008). The determination of the MBV only requires simple and fast cyclic step-change (de)sorption measurements, and is applicable for homogeneous one-dimensional finishes as well as for multimaterial and/or multidimensional interior elements. Sensitivity analysis (Roels and Janssen, 2006) demonstrated that for a dependable single-element MBP characterisation, measurements should be made with (1) $\mathrm{RH}$ levels in accordance with the expected ambient $\mathrm{RH}$, (2) samples with build-up and dimensions similar to practice, (3) surface mass transfer coefficients as anticipated in practice and (4) time intervals in agreement with the likely moisture production.

Although the moisture production scheme in for example offices or bedrooms agrees often reasonably well with the NT's 8/16h loading/unloading scheme, the production scheme in bathrooms, kitchens, ... is more variable. This wide variation in moisture production schemes renders the last criterion very demanding. To avoid that a variety of MBV-values is needed to characterise an element in an unambiguous way, Janssen and Roels (2009) introduced a production-interval adapted $\mathrm{MBV}^{*\left({ }^{(}\right)}$:

$$
M B V^{*()}=\alpha \cdot M B V_{8 h}^{()}+(1-\alpha) \cdot M B V_{1 h}^{()}
$$

with $\mathrm{MBV}_{1 \mathrm{~h} / 8 \mathrm{~h}}^{(')}$ the MBV-value measured on respectively the first and eighth hour and $\alpha(-) \mathrm{a}$ weighting factor depending on the production scheme. Note that $\mathrm{MBV}_{1 \mathrm{~h}}$ and $\mathrm{MBV}_{8 \mathrm{~h}}$ are determined in the same experiment as illustrated in Figure 1. Three production schemes with corresponding $\alpha$ are proposed (Janssen and Roels, 2009):
o Short:
0 hour $<$ production interval $\leq 2$ hour
$\alpha=0.0$
○ Peak:
2 hour $<$ production interval $\leq 6$ hour
$\alpha=0.5$
○ Long:
6 hour $<$ production interval $\leq 10$ hour
$\alpha=1.0$

When more accurate information about the production interval is available, a more accurate weighting factor can be determined by interpolation.

A numerical study (Janssen and Roels, 2009) showed a strong uniqueness between the $\mathrm{MBV}^{*}$ and the dampening of the interior relative humidity, independent of the production scheme. Consequently, the production-interval adapted $\mathrm{MBV}^{*}$ is shown to be a dependable characterisation of the single-element MBP, applicable for different production schemes.

\section{Room-enclosure MBP characterisation}

The test protocol to determine the $\mathrm{MBV}^{*\left({ }^{(}\right)}$is easy to perform and straightforward, but its application is currently restricted to single elements. Real rooms on the other hand are generally cladded with several finishes and interior objects as furniture, decoration, carpets, drapes, books, etc. Following Ramos and de Freitas (2006), a room's hygric inertia can be defined as:

$$
H I R=\left(\sum A_{k} \cdot M B P_{k}+\sum M B P_{l}^{\prime}\right) / V
$$

with $\operatorname{HIR}\left(\mathrm{kg} /\left(\mathrm{m}^{3} . \% \mathrm{RH}\right)\right)$ the hygric inertia per cubic meter of room volume, $\mathrm{MBP}_{\mathrm{k}}$ $\left(\mathrm{kg} /\left(\mathrm{m}^{2} . \% \mathrm{RH}\right)\right)$ and $A_{k}\left(\mathrm{~m}^{2}\right)$ respectively the moisture buffer potential and area of finish $k$, MBP', (kg/\%RH) the equivalent moisture buffer potential of object $I$ and $V\left(\mathrm{~m}^{3}\right)$ the volume of the room. Generalising Eq.(7) to a production-interval adapted HIR* characterisation, the following equation is obtained:

$$
H I R^{*}=\left(\sum A_{k} \cdot M B V_{k}^{*}+\sum M B V_{l}^{* *}\right) / V=\alpha \cdot H I R_{8 h}+(1-\alpha) \cdot H I R_{1 h}
$$


Postprint: Vereecken E, Roels S, Janssen H, 2011. In situ determination of the moisture buffer potential of room enclosures, Journal of Building Physics, 34(3): 223-246.

doi: $10.1177 / 1744259109358268$

with $\mathrm{HIR}_{8 \mathrm{~h} / \mathrm{h}}\left(\mathrm{kg} /\left(\mathrm{m}^{3} . \% \mathrm{RH}\right)\right)$ the long/short term inertia and $\alpha$ the weighting factor depending on the moisture production scheme concerned (see above).

Simulations (Janssen and Roels, 2009) executed for different surface area's and combinations of finishing materials, showed an acceptably unique relationship between the dampening of the interior $\mathrm{RH}$-variation and the $\mathrm{HIR}^{*}$-value. Consequently, the $\mathrm{HIR}^{*}$-value makes it possible to superpose the MBP's of different elements to the room level. The next section will show that the defined $\mathrm{HIR}^{\star}$ also allows to quantify the moisture buffering effect.

\section{IMPLEMENTATION OF THE HIR*-VALUE IN THE MOISTURE BALANCE OF ROOM ENCLOSURES}

\section{Effective capacitance model}

Although some sources give rough minimum and maximum values to enlarge the moisture capacity of the indoor air used in the effective capacitance model (e.g. Stehno, 1982; TRNSYS 16)), a more reliable value can be obtained by assuming that the mass of moisture buffered in the hygroscopic materials $M_{\text {buf }}(\mathrm{kg})$ is proportional to the $\mathrm{HIR}^{*}$-value of the room enclosure (Janssen and Roels, 2009). Consequently, the water vapour exchange between room and enclosure $G_{\text {buf }}$ can be written as:

$$
G_{b u f}=\frac{\partial M_{b u f}}{\partial t}=\frac{100 H I R^{*} V}{p_{v, s a t}\left(T_{i}\right)} \cdot \frac{\partial p_{v i}}{\partial t}
$$

with 100 a unit conversion factor to bring the $\mathrm{kg} /\left(\mathrm{m}^{3} . \% \mathrm{RH}\right)$ unit of $\mathrm{HIR}^{*}$ back to $\mathrm{kg} / \mathrm{m}^{3}$. Eq.(9) transforms Eq.(1) into:

$$
\left(\frac{V}{R_{v} T_{i}}+\frac{100 H I R^{*} V}{p_{v, s a t}\left(T_{i}\right)}\right) \cdot \frac{\partial p_{v i}}{\partial t}=\left(p_{v e}-p_{v i}\right) \cdot \frac{n V}{3600 R_{v} T_{i}}+G_{v p}
$$

The underlying assumption is however, that the mass of moisture buffered in the hygroscopic materials is at any moment in equilibrium with the room humidity (Stehno, 1982). As a consequence the effective capacitance model yields reasonable estimates of the minima and maxima of indoor humidity, but is unable to predict the exact course of indoor humidity variations since the time dependent behaviour of moisture storage is not included.

However, despite the impossibility of the EC-model to predict the real $\mathrm{RH}$-course, the ECmodel can be pointed out as a very usable model. After all, to include the buffering effect of the whole room enclosure, only the $\mathrm{HIR}^{*}$-value is required. Moreover, the $\mathrm{RH}$ minima and maxima are the main elements when checking surface condensation, optimising the HVACinstallation, etc. and will be consequently often suffice to analyse most problems.

\section{Effective moisture penetration depth model}

When one wants to predict the $\mathrm{RH}$-course more accurately, the effective moisture penetration depth model should be used. Though, to use the EMPD-model, the moisture penetration depth - for which the moisture capacity and vapour permeability is needed - has to be known. The determination of these properties are often time-consuming, labour intensive or even not well-defined for interior finishes with (multiple) finite-thickness layer(s).

Instead of solving Eq.(2) separately for all available humidity buffering finishes (e.g. EnergyPlus, 2005), all interior elements can also be lumped into one equivalent buffer layer. To do so, a fictitious buffer layer should be defined with a similar storage behaviour as found in reality. Janssen and Roels (2009) presented a methodology to transform the $\mathrm{HIR}^{*}$-value to an equivalent single buffer layer, which can be used in the EMPD-model. The thickness $d_{b}$ of this buffer layer is commonly related to the effective moisture penetration depth $d_{p}(\mathrm{~m})$ which in turn depends on the period of the humidity variations in the room (Cunningham, 2003): 
Postprint: Vereecken E, Roels S, Janssen H, 2011. In situ determination of the moisture buffer potential of room enclosures, Journal of Building Physics, 34(3): 223-246.

doi: $10.1177 / 1744259109358268$

$$
d_{b}=a \cdot d_{p}=a \cdot \sqrt{\frac{t_{p} \cdot \delta \cdot p_{v, s a t}\left(\theta_{b}\right)}{\pi \cdot \xi}} \quad a=\min \left(d / d_{p}, 1\right)
$$

with $t_{p}$ (s) the cycling time and $a(-)$ an adjustment factor to take into account that the thickness of the buffer layer cannot be larger than the actual thickness $d(\mathrm{~m})$.

Using Eq.(11), for a single homogeneous material Eq.(2) can be written as:

$$
A \cdot \frac{p_{v i}-p_{v b}}{\frac{1}{\beta_{i}}+a \cdot \sqrt{t_{p} / \pi} /(2 . b)}=A \cdot a \cdot \sqrt{t_{p} / \pi} \cdot b \cdot \frac{\partial p_{v b}}{\partial t} \quad a=\min \left(d / d_{p}, 1\right)
$$

with $b\left(\mathrm{~s}^{3 / 2} / \mathrm{m}\right)$ the material's hygric effusivity.

Consequently, the material's hygric effusivity $b$ and the thickness adjustment factor $a$ are sufficient to describe the moisture buffering of an element. Janssen and Roels (2009) showed that both values can also be obtained from $\mathrm{MBV}^{*} / \mathrm{HIR}^{*}$-values, using the analytical solution given in (Carslaw and Jaeger, 1990):

$$
\begin{array}{r}
M B V_{e q, 8 h / 1 h}=a_{e q} \cdot \sqrt{\frac{t_{p}}{\pi}} \cdot b_{e q} \cdot \Delta p_{v i} \cdot\left(1-\sum_{i=1}^{\infty}\left(\frac{2 \omega^{2}}{\gamma_{i}^{2}\left(\omega(\omega+1)+\gamma_{i}^{2}\right)} \cdot \exp \left(-\gamma_{i}^{2} \tau\right)\right)\right) \\
\text { with } \omega=\frac{a_{e q} \cdot \beta}{b_{e q}} \cdot \sqrt{\frac{t_{p}}{\pi}}, \tau=\frac{\pi \cdot t_{8 h / 1 h}}{a_{e q}^{2} \cdot t_{p}} \text { and } \gamma_{i} \text { roots of } \gamma \cdot \tan (\gamma)=\omega
\end{array}
$$

In this, $\mathrm{MBV}_{\text {eq,8h/1h }}$ is an equivalent MBV-value for respectively the eighth and first hour, which can bring several finishes and elements into account and can be determined using:

$$
H I R_{8 h / 1 h}=\frac{\sum A_{k} \cdot M B V_{k, 8 h / 1 h}+\sum M B V_{l, 8 h / 1 h}^{\prime}}{V}=\frac{A_{T O T} \cdot M B V_{e q, 8 h / 1 h}}{V}
$$

So knowing $\mathrm{HIR}_{8 \mathrm{~h}}$ and $\mathrm{HIR}_{1 \mathrm{~h}}$, the equivalent effusivity $b_{e q}$ and adjustment factor $a_{e q}$ of the single buffer layer of the complete room enclosure can be obtained from Eq.(13), with $t_{p}$ (s) 24 hour and $t_{8 h / 1 h}$ (s) 8 and 1 hour respectively. Note that to determine $b_{e q}$ and $a_{e q}$ also the total exchange surface $A_{T O T}$ should be known, which is not evident in case of a room with multiple hygroscopic interior elements. Janssen and Roels (2009) showed however that a rough estimation of this exchange surface is already sufficient. Consequently, also the EMPDmodel makes it possible to take the entire room enclosure into account.

\section{PROPOSED METHOdOLOGY FOR IN SITU DETERMINATION OF HIR ${ }^{\star}$}

Although the introduced $\mathrm{HIR}^{*}$-value can be determined based on the MBV*'s of the different elements in a room, the abundance of finishes and objects in a room makes the determination of it a time-consuming and often impossible job. Therefore, in the current study, instead of calculating the hygric inertia of building enclosures from the moisture buffer value of the contributing components, a methodology is proposed to determine the hygric inertia directly by inversely fitting the moisture balance (Eq.(10)).

\section{In situ measurement}

In a first step of the proposed methodology, a measurement of the hygroscopic buffering of the building enclosure is made in situ, by recording the temperature and $\mathrm{RH}$ evolution inside the room in response to a moisture production event. A humidifier inside the room is preset to be active during a certain period and the amount of evaporated water is continuously logged. Beforehand, all joints (around windows, doors,...) and other possible air leaks are sealed, to reduce the ventilation rate inside the room as much as possible. To start from 
Postprint: Vereecken E, Roels S, Janssen H, 2011. In situ determination of the moisture buffer potential of room enclosures, Journal of Building Physics, 34(3): 223-246.

more stabilized room-conditions, the humidifier is preset to start working a day after entirely sealing the room.

Due to the imposed moisture production an initial rise of interior $\mathrm{RH}$ is obtained, followed by a fall of interior $\mathrm{RH}$ during the period without moisture production. Furthermore, this $\mathrm{RH}$ increase and $\mathrm{RH}$-decrease will depend on the remaining air change rate $(\mathrm{ACH})$, the outdoor air conditions and the moisture buffering of the room enclosure. For a certain $\mathrm{HIR}^{*}$-value, the $\mathrm{RH}$-increase will diminish when increasing the $\mathrm{ACH}$ (Figure 2a). For the $\mathrm{RH}$-decrease, raising the $\mathrm{ACH}$ will result in a lower $\mathrm{RH}$ at the end of the period without moisture production. With a zero $\mathrm{ACH}$ almost no $\mathrm{RH}$-decrease would occur.

Higher $\mathrm{HIR}^{*}$-values result in a smaller $\mathrm{RH}$-increase and decrease (Figure $2 \mathrm{~b}$ ). But analogous to the declining extra heat resistance corresponding to the extra addition of insulation, the influence of the addition of the first hygroscopic finishes/elements will be the largest.

\section{Theoretical total $\mathrm{RH}$-increase and decrease in function of the $\mathrm{ACH}$}

Based on Eq.(10), for a certain $\mathrm{HIR}^{*}$-value the amplitude of the theoretical $\mathrm{RH}$-increase and $\mathrm{RH}$-decrease (as defined in Figure 2a) can be calculated and plotted in function of the $\mathrm{ACH}$, as shown in Figure 2c. The curve which represents the theoretical total $\mathrm{RH}$-increase in function of the $\mathrm{ACH}$ (dotted line) shows a descending course. This can be easily explained by the diminution in $\mathrm{RH}$-increase shown by the dotted lines in Figure 2a. On the other hand, the curve corresponding to the theoretical total $\mathrm{RH}$-decrease in Figure 2c (continuous line) first shows a rising course, followed by a descending course. This can be explained based on the 3 curves in Figure 2a. As already mentioned, an $\mathrm{ACH}=0$ would keep the $\mathrm{RH}$ almost at the value obtained due to the imposed moisture production (curve 1). Increasing the ACH first results in an increase of the $\mathrm{RH}$-amplitude since a larger $\mathrm{ACH}$ corresponds to a lower $\mathrm{RH}$ at the end of the period without moisture production (curve 2 compared to curve 1). However, an increasing $\mathrm{ACH}$ also affects the $\mathrm{RH}$-increase during the moisture production period, and this feature dominates over the extra decrease in the period without moisture production above a certain $\mathrm{ACH}$ (curve 3 compared to curve 2). Consequently, the total $\mathrm{RH}$-decrease becomes smaller and the curve corresponding to the theoretical $\mathrm{RH}$-decrease shows a descending course above a certain $\mathrm{ACH}$.

\section{Determination of the HIR $^{\star}$-value}

To determine the $\mathrm{HIR}^{*}$-value of a room from the in situ experiments, the curves of the total theoretical $\mathrm{RH}$-increase and decrease are calculated based on Eq.(10) and plotted for different $\mathrm{HIR}^{*}$-values in function of the $\mathrm{ACH}$ (Figure 3). Assuming that the $\mathrm{ACH}$ remains constant during the experiment, the measured $\mathrm{RH}$-increase and decrease have to intersect the predicted $\mathrm{RH}$-changes for the same $\mathrm{HIR}^{*}$-value and $\mathrm{ACH}$ (indicated by the dots in Figure 3). In this way the hygric inertia of the whole building enclosure can be determined by a simple and fast experiment. To increase the reliability of the experiment, a few cycli can be executed. A possible variation in temperature is included in the curves, since the vapour pressure appears in Eq.(10). Note however that the methodology is not valid when condensation occurs (e.g. light coloured part of the curves of $\mathrm{HIR}^{*}=0.0$ and $\mathrm{HIR}^{*}=0.2 \mathrm{~g} /\left(\mathrm{m}^{3} . \% \mathrm{RH}\right)$ ).

\section{Moisture production scheme}

The moisture production period can be chosen in agreement with the most frequent production scheme in the room. However, a more all-embracing methodology is to determine the long term hygric inertia ( 8 hours humidifying, followed by 16 hours of inactivity) and the short term hygric inertia (cycli of 1 hour humidifying, followed by 5 hours of inactivity), based on which the production-interval adapted $\mathrm{HIR}^{*}$ for different production schemes can be determined, according to Eq.(8).

Executing a long term experiment, also the buffering potential of the room in case of a shorter production scheme (e.g. 1 hour) could be determined. For this, the measured $\mathrm{RH}-$ increase after one hour humidification has to intersect the theoretical $\mathrm{RH}$-increase for the 
Postprint: Vereecken E, Roels S, Janssen H, 2011. In situ determination of the moisture buffer potential of room enclosures, Journal of Building Physics, 34(3): 223-246.

doi: $10.1177 / 1744259109358268$

$\mathrm{ACH}$ obtained in the determination of the long term hygric inertia. It will be shown in the next section however that an extra experiment to determine the short term hygric inertia is more reliable.

\section{VALIDATION}

\section{Test setup in the VLIET-test building}

To validate the proposed methodology, different finishing materials and objects were placed in a test room $(1.8 \mathrm{~m} \times 6.54 \mathrm{~m} \times 2.7 \mathrm{~m})$ in the VLIET-test building of the K.U.Leuven (Figure 4). Beforehand $\mathrm{MBV}_{1 \mathrm{~h}}$ and $\mathrm{MBV}_{8 \mathrm{~h}}$ of all elements were determined according to the test protocol in a climatic chamber, as described in (Roels and Janssen, 2006). Table 1 gives an overview of all elements placed in the test room together with their moisture buffer potential. Using these values in Eq.(8) results in a $\mathrm{HIR}_{8 \mathrm{~h}}$ of $0.51 \mathrm{~g} /\left(\mathrm{m}^{3} . \% R H\right)$ and a $\mathrm{HIR}_{1 \mathrm{~h}}$ of $0.16 \mathrm{~g} /\left(\mathrm{m}^{3} . \% R H\right)$. The influence of the outdoor conditions was minimized since the chamber was well air and vapour tight. To avoid moisture buffering by other than the studied elements, the walls consisting of materials which are able to buffer moisture were covered with plastic foil. Further, the back and the edges of the finishing materials were sealed with respectively plastic foil and aluminum tape. To mix the vapour in the room air, a small ventilator was placed behind the humidifier. A long term and a short term experiment were executed.

\section{Validation of the EC-model based methodology}

Applying the proposed graphical method for the long term experiment resulted in a $\mathrm{HIR}_{8 \mathrm{~h}^{-}}$ value of $0.59 \mathrm{~g} /\left(\mathrm{m}^{3} . \% \mathrm{RH}\right)$ (for the determination, see Figure 3), which is in close agreement with the calculated value based on the $\mathrm{MBV}^{*}$-values of the different elements $(0.51$ $\left.\mathrm{g} /\left(\mathrm{m}^{3} . \% \mathrm{RH}\right)\right)$. A small $\mathrm{ACH}\left(0.1 \mathrm{~h}^{-1}\right)$ was obtained, which agrees with the expectations since the precise air tight sealing of the test room. Figure 5 shows the implemented vapour production together with a comparison of the measured $\mathrm{RH}$-course and the $\mathrm{RH}$-course obtained from the EC-model for both the $\mathrm{HIR}_{8 \mathrm{~h}}$-values. As can be seen, the maximum and minimum $\mathrm{RH}$ obtained with the in situ determined $\mathrm{HIR}_{8 \mathrm{~h}}$ correspond to the measured values, since they were the input for the determination of the HIR-value. When using the $\mathrm{HIR}_{8 \mathrm{~h}}$-value calculated with Eq.(8), the maximum and minimum $\mathrm{RH}$ are also fairly well predicted.

However, application of the same methodology for a short term experiment (1 hour humidifying, followed by 5 hours of inactivity) resulted in an underestimation $\left(\mathrm{HIR}_{1 \mathrm{~h}}\right.$-value of 0.07 $\mathrm{g} /\left(\mathrm{m}^{3} . \% \mathrm{RH}\right)$ compared to the with Eq.(8) calculated value $\left(0.16 \mathrm{~g} /\left(\mathrm{m}^{3} . \% \mathrm{RH}\right)\right)$. Although, this short term measurement result gives a crucial improvement over the value deduced from the $\mathrm{ACH}$ and $\mathrm{RH}$-increase during the first hour of the long term experiment $\left(0.04 \mathrm{~g} /\left(\mathrm{m}^{3} . \% \mathrm{RH}\right)\right)$.

Figure 6 shows the moisture production of the short term experiment together with a comparison of the measured and the determined $\mathrm{RH}$-course. The difference between the with Eq.(8) calculated and in situ determined $\mathrm{HIR}_{1 \mathrm{~h}}$-value can probably be attributed to some experimental facts as a different surface transfer coefficient in the room and the climatic chamber, the larger volume of the room compared to the chamber, the difference between the $\mathrm{RH}$-level in the room and the chamber, the fact that the water vapour will rise while most elements were placed on the ground,... Note also that in the short term experiment, the materials were exposed to a small $\mathrm{RH}$-change, which may lead to an underestimation of the moisture buffer potential. To become a more accurate value a larger moisture production scheme should be imposed.

As can be seen in both cases, the simulations with the EC-model are only able to predict the expected minimum and maximum and not the exact $\mathrm{RH}$-course. This is an inherent shortcoming of the EC-model, due to the assumption that the $\mathrm{RH}$ in the materials is always in equilibrium with the room. 
Postprint: Vereecken E, Roels S, Janssen H, 2011. In situ determination of the moisture buffer potential of room enclosures, Journal of Building Physics, 34(3): 223-246.

doi: $10.1177 / 1744259109358268$

\section{Validation of the EMPD-model based methodology}

To predict the exact course of the interior $\mathrm{RH}$, the EMPD-model can be used. For this, the equivalent effusivity $b_{e q}$, the correction factor $a_{e q}$ and the total surface area of buffering materials $A_{T O T}$ in Eq.(12) and the $\mathrm{ACH}$ should be known. Calculating the exposed surfaces of all the materials in the test room (Table 1) results in an $A_{T O T}$ of $11.53 \mathrm{~m}^{2}$. Theoretical, the parameters $b_{e q}, a_{e q}$ and $\mathrm{ACH}$ can be determined calculating and plotting the curves (total $\mathrm{RH}$ increase or decrease in function of the $\mathrm{HIR}^{*}$-value) with the EMPD-model. Therefore, for each $\mathrm{HIR}^{*}$-value the matching $a_{e q}$ and $b_{e q}$ should be determined using Eq.(13-14). However, in practice the curves are hard to determine due to numerical difficulties. A better method is to estimate $A_{T O T}$ and to fit the parameters $a_{\text {eq }}, b_{\text {eq }}$ of the EMPD-model and the ACH, by means of a least-squares fit between measured and predicted $\mathrm{RH}$ courses. In this process, $b_{e q}$ should be the same for the different moisture production schemes. The factor $a_{e q}$ depends of the moisture production scheme, as in case of a shorter moisture production a thinner moisture buffer layer will be used. In this procedure, ACH is held constant per 6 hours. The obtained values for $b_{e q}, a_{e q}$ and the matching $\mathrm{RH}$-course for the short and long moisture production scheme are given in Figure 7. As can be seen a good agreement between the measured and predicted $\mathrm{RH}$-course is obtained.

\section{Comparison of the results obtained with the EC-model and the EMPD-model}

To compare the results obtained with the EC-model with those obtained with the EMPDmodel, the $A_{T O T}$, equivalent effusivity $b_{e q}$ and correction factor $a_{e q}$ of the long term moisture production scheme are translated into the matching HIR-values, using Eq.(13-14). This results in a HIR $\mathrm{H}_{1 \mathrm{~h}}$ of $0.18 \mathrm{~g} /\left(\mathrm{m}^{3} . \% \mathrm{RH}\right)$ and a $\mathrm{HIR}_{8 \mathrm{~h}}$ of $0.40 \mathrm{~g} /\left(\mathrm{m}^{3} . \% \mathrm{RH}\right)$, which are in close agreement with respectively the calculated $H_{I R}$ of $0.16 \mathrm{~g} /\left(\mathrm{m}^{3} . \% R H\right)$ and $H_{12} R_{8 h}$ of 0.51 $\mathrm{g} /\left(\mathrm{m}^{3} . \% \mathrm{RH}\right)$ obtained with Eq.(8). Table 2 summarizes the HIR-values obtained with the different methods. Note that, in contrast with the EC-model, using the EMPD-model results in a good agreement between the in situ determined HIR-value and the value based on the moisture buffer values, also for the short term hygric inertia.

\section{APPLICATION ON A STUDENT ROOM}

\section{Test setup in a student room}

To assess the size of the hygric inertia of a real room, the developed methodology is applied to a student room $(5 \mathrm{~m} \times 2.8 \mathrm{~m} \times 2.5 \mathrm{~m})$. Figure 8 gives an inside view of the room. The walls of the room are constructed with autoclaved aerated concrete finished with coated gypsum plaster. Floor and ceiling consist of a concrete slab finished with linoleum on top and coated gypsum plaster at the bottom. To reduce the $\mathrm{ACH}$, possible air leaks around windows and doors were sealed with plastic foil. After one day stabilizing the room conditions, a three days moisture production scheme was imposed consisting of cycli of 8 hours humidifying, followed by 16 hours without moisture production.

\section{Results}

Using the data of the first day, a $\mathrm{HIR}_{8 \mathrm{~h}}$-value of $0.72 \mathrm{~g} /\left(\mathrm{m}^{3} . \% \mathrm{RH}\right)$ and a $\mathrm{HIR}_{1 \mathrm{~h}}$ of 0.18 $\mathrm{g} /\left(\mathrm{m}^{3} . \% \mathrm{RH}\right)$ were obtained. In the determination, assumption was made that all infiltration air was coming from outside.

Figure 9a compares the measured and the EC-predicted RH-courses. As can be seen the predicted minimum and maximum $\mathrm{RH}$ during the first day agree with the measured values, since these were the input in the determination of the HIR-value. Furthermore, when using the HIR-value determined during the first day also a good agreement of the minimum and maximum $\mathrm{RH}$ during the next days is obtained.

Also here, the exact course can be predicted using the EMPD-model. An estimation of $166 \mathrm{~m}^{2}$ is made for the exposed surface of the buffering materials and the equivalent effusivity $b_{\text {eq }}$, 
Postprint: Vereecken E, Roels S, Janssen H, 2011. In situ determination of the moisture buffer potential of room enclosures, Journal of Building Physics, 34(3): 223-246.

doi: $10.1177 / 1744259109358268$

the correction factor $a_{e q}$ and the ACH are determined using the solver in Excel. The EMPDpredicted and the measured $\mathrm{RH}$-courses are given in Figure 9b. As can be seen with the EMPD-model the exact $\mathrm{RH}$-course is predicted. Using the determined $b_{e q}$ and $a_{e q}$ in Eq.(13-

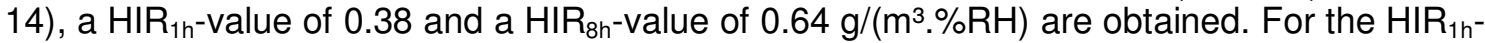
value, this is more than double the value obtained with the EC-model $\left(0.18 \mathrm{~g} /\left(\mathrm{m}^{3} . \% R H\right)\right)$. The latter $\mathrm{HIR}_{1 \mathrm{~h}}$-value was however deduced from the $\mathrm{ACH}$ and $\mathrm{RH}$-increase during the first hour of the long term experiment and can consequently considered as a less reliable value. For the $\mathrm{HIR}_{8 \mathrm{~h}}$-value, a good agreement between the values obtained with both models is found. The small difference can be due to the $\mathrm{ACH}$ which was assumed constant during the entire day in the EC-model while varied per 6 hours in the EMPD-model.

\section{CONCLUSION}

Interior humidity is known to have an important influence on the health and comfort of building occupants, the durability of building components and the energy performance of building zones. Recently, more and more attention is going to the influence of moisture buffering by room enclosures on the $\mathrm{RH}$-variation. To qualitatively and quantitatively characterise this moisture buffering effect the HIR*-value (Janssen and Roels, 2009) can be used, which can be determined based on the moisture buffer potential of the different elements and finishes separately. However, the determination of the moisture buffering potential of all finishes and objects in a building enclosure remains time-consuming and is often unrealistic. To overcome this problem, this paper proposed a methodology to determine the moisture buffering potential of room enclosures (the HIR*-value) in situ. To do so, a humidifier was placed in the room, preset to be active during a certain period. Temperature, $\mathrm{RH}$ and evaporated water were logged continuously. The $\mathrm{ACH}$ and $\mathrm{HIR}^{*}$-value were inversely fitted, solving the moisture balance of the room with the EC-model or EMPD-model. The methodology has been validated in an air and vapour tight sealed test room. The in situ determined $\mathrm{HIR}_{8 \mathrm{~h}}$ showed to be in close agreement with the value calculated based on the moisture buffer values of the different contributing elements. Prediction of the short term hygric inertia was less accurate when using the EC-model. This could most probably be attributed to the small moisture production. To have a more accurate prediction of the $\mathrm{HIR}_{1 \mathrm{~h}}$-value a larger moisture production should be provided. Using the EMPD-model, also for the short term hygric inertia a good agreement between the in situ determined HIR-value and the value based on the moisture buffer values is found.

In a next step the application on a student room with unknown hygric inertia showed the possibilities of the approach. Here, a $H I R_{8 h}$ of $0.72 \mathrm{~g} /\left(\mathrm{m}^{3} . \% R H\right)$ and a $H I R_{1 h}$ of $0.18 \mathrm{~g} /\left(\mathrm{m}^{3} . \% R H\right)$ were found when using the EC-model. Using the EMPD-model, a HIR $\mathrm{R}_{1 \mathrm{~h}}$-value of 0.38 and a $\mathrm{HIR}_{8 \mathrm{~h}}$-value of $0.64 \mathrm{~g} /\left(\mathrm{m}^{3} . \% \mathrm{RH}\right)$ were obtained.

Although in the EC-model based method some assumptions as a constant $\mathrm{ACH}$ for an entire day, only outdoor infiltration, etc. were made, the obtained value of the long term experiment showed to give already a good indication of the hygric inertia of a room. Consequently, the main advantage of the methodology is that a simple and fast experiment allows to obtain the $\mathrm{HIR}^{*}$-value. This value makes - compared to the standard methodologies - a comprehensive characterisation of the hygric inertia of a building enclosure possible, since also multilayered interior finishes and multidimensional interior object such as furniture, carpets, books, etc. are easily taken into account. Furthermore, the determined $\mathrm{HIR}^{\star}$-value can easily be implemented in the EC-model to predict the minimum and maximum interior humidity. To predict the exact $\mathrm{RH}$-course, the EMPD-model should be used. Therefore, the exposed surface of buffering materials is estimated and the equivalent effusivity $b_{\text {eq }}$, thickness adjustment factor $a_{e q}$ and $\mathrm{ACH}$ are determined by minimizing the difference between predicted and measured $\mathrm{RH}$-course.

Using the in situ method, the moisture buffer potential of different types of rooms (living room, kitchen, bedroom, office, bathroom, etc.) can be determined. Based on these values 
Postprint: Vereecken E, Roels S, Janssen H, 2011. In situ determination of the moisture buffer potential of room enclosures, Journal of Building Physics, 34(3): 223-246.

doi: $10.1177 / 1744259109358268$

more reliable parameters to implement the moisture buffering influence in simulation programs as EnergyPlus or TRNSYS can be suggested, so a more accurate design-tool is obtained.

\section{NOMENCLATURE}

Symbols

\begin{tabular}{|c|c|}
\hline A & Area $\left(m^{2}\right)$ \\
\hline a & Adjustment factor (-) \\
\hline $\mathrm{A}_{\text {TOT }}$ & Total exchange surface $\left(\mathrm{m}^{2}\right)$ \\
\hline b & Hygric effusivity $\left(\mathrm{s}^{3 / 2} / \mathrm{m}\right)$ \\
\hline d & Actual thickness (m) \\
\hline$d_{b}$ & Thickness humidity buffer layer (m) \\
\hline$d_{p}$ & Penetration depth $(\mathrm{m})$ \\
\hline $\mathrm{G}_{\text {buf }}$ & Moisture exchange between indoor air and all interior hygroscopic elements $(\mathrm{kg} / \mathrm{s})$ \\
\hline $\mathrm{G}_{\mathrm{vp}}$ & Indoor vapour production (kg/s) \\
\hline M & Enlargement factor for the capacity of the zone air (-) \\
\hline$M_{\text {buf }}$ & Mass of moisture buffered in the hygroscopic materials $(\mathrm{kg})$ \\
\hline $\mathrm{m}_{\max / \min }$ & Maximum/minimum moisture mass $(\mathrm{kg})$ \\
\hline $\mathrm{n}$ & Air change rate per hour $(1 / \mathrm{h})$ \\
\hline $\mathrm{p}_{\mathrm{vb}}$ & Vapour pressure in the centre of the humidity buffer $(\mathrm{Pa})$ \\
\hline $\mathrm{p}_{\mathrm{vi} / \mathrm{e}}$ & Partial vapour pressure of indoor/outdoor air $(\mathrm{Pa})$ \\
\hline$p_{\text {vsat }}$ & Saturation vapour pressure $(\mathrm{Pa})$ \\
\hline $\mathrm{RH}$ & Relative humidity (\%) \\
\hline $\mathrm{R}_{\mathrm{v}}$ & Gas constant for water vapour $(=462 \mathrm{~J} /(\mathrm{kg} . \mathrm{K}))$ \\
\hline $\mathrm{t}$ & Time $(s)$ \\
\hline $\mathrm{T}_{\mathrm{b}}$ & Temperature in the centre of the humidity buffer layer $(\mathrm{K})$ \\
\hline $\mathrm{T}_{\mathrm{i}}$ & Indoor air temperature $(\mathrm{K})$ \\
\hline$t_{p}$ & Cycling time (s) \\
\hline V & Volume $\left(m^{3}\right)$ \\
\hline
\end{tabular}

Greek symbols

$\delta \quad$ Water vapour permeability (of the buffer layer) (s)

$\xi \quad$ Moisture capacity (of the buffer layer) $\left(\mathrm{kg} / \mathrm{m}^{3}\right)$

$\beta \quad$ Surface mass transfer coefficient $(\mathrm{s} / \mathrm{m})$

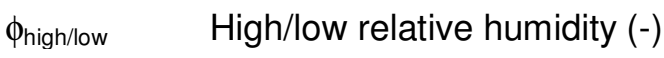

$\alpha \quad$ Weighting factor (-)

$\theta_{b} \quad$ Temperature in the centre of the humidity buffer layer $\left({ }^{\circ} \mathrm{C}\right)$

\section{Acronyms}

$\begin{array}{ll}\text { ACH } & \text { Air Change Rate } \\ \text { DIS } & \text { Draft International Standard } \\ \text { EC } & \text { Effective Capacitance }\end{array}$


Postprint: Vereecken E, Roels S, Janssen H, 2011. In situ determination of the moisture buffer potential of room enclosures, Journal of Building Physics, 34(3): 223-246.

doi: $10.1177 / 1744259109358268$

$\begin{array}{ll}\text { EMPD } & \text { Effective Moisture Penetration Depth } \\ \text { HIR } & \text { Hygric inertia of a room }\left(\mathrm{kg} /\left(\mathrm{m}^{3} . \% \mathrm{RH}\right)\right) \\ \text { JIS } & \text { Japanese Industrial Standard } \\ \text { MBP } & \text { Moisture Buffer Potential } \\ \text { MBV } & \text { Moisture Buffer Value }\left(\mathrm{kg} /\left(\mathrm{m}^{2} . \% \mathrm{RH}\right)\right. \\ \text { MBV } & \text { Moisture Buffer Value }(\mathrm{kg} / \% \mathrm{RH}) \\ \text { NT } & \text { Nordtest }\end{array}$

\title{
Subscripts
}

$\begin{array}{ll}\text { 1h } & 1 \text { hour } \\ 8 \mathrm{~h} & 8 \text { hour } \\ \mathrm{k} & \text { Finish } \mathrm{k} \\ \mathrm{I} & \text { Object I } \\ \text { eq } & \text { Equivalent }\end{array}$

\author{
Superscripts \\ * $\quad$ Adapted
}

\section{ACKNOWLEDGEMENTS}

The results in this paper have been partially obtained within IWT SBO 050154 'Heat, air and Moisture Performance Engineering: a whole building approach', funded by the Flemish Government and IWT 3E90050 'Global performance approach and economic analysis of interior insulation with regard to renovation projects' funded by the Flemish Government. These financial supports are gratefully acknowledged.

\section{REFERENCES}

Carslaw, H.S. and Jaeger, J.C. (1990). Conduction of heat in solids (second edition), At the Claredon Press, Oxford, United Kingdom.

Cunningham, M.J. (2003). The building volume with hygroscopic materials - an analytic study of a classical building physics problem, Building and Environment, 38: 329-337. Energyplus (2005)

Fang, L., Clausen, G., Fanger, P.O. (1998). Impact of temperature and humidity on the perception of indoor air quality, Indoor Air, 8(2): 80-90.

Hameury, S. (2005). Moisture buffering capacity of heavy timber structures directly exposed to an indoor climate: a numerical study, Building and Environment, 40: 1400-1412.

Hens, H. (2008). IEA-ECBCS Annex 41 Whole building heat, air and moisture response. Proceedings of the IEA ECBCS Annex 41 Closing Seminar, Copenhagen, June 19, 2008 Holm, A.H., Kunzel, H.M., Sedlbauer, K. (2004). Predicting indoor temperature and humidity conditions including hygrothermal interactions with the building envelope, ASHRAE Transactions, 110 (2): 820-826.

ISO/DIS 24353. (2006). Hygrothermal performance of building materials and products - determination of moisture adsorption/desorption properties in response to humidity variation. Janssen, H., Roels, S. (2009). Qualitative and quantitative assessment of interior moisture buffering by enclosures, Energy and Buildings, 41: 382-394. 
Postprint: Vereecken E, Roels S, Janssen H, 2011. In situ determination of the moisture buffer potential of room enclosures, Journal of Building Physics, 34(3): 223-246.

doi: $10.1177 / 1744259109358268$

JIS A 1470-1. (2002). Test method of adsorption/desorption efficiency for building materials to regulate an indoor humidity - part 1: response method of humidity.

Kerestecioglu, A., Swami, M., Kamel, A. (1989). Theoretical and computational investigation of simultaneous heat and moisture transfer in buildings: effective penetration depth theory, ASHREA Winter meeting, Atlanta GA.

Kurnitski, J., Kalamees, T., Palonen, J., Eskola, L., Seppänen, O. (2007). Potential effects of permeable and hygroscopic lightweight structures on thermal comfort and perceived IAQ in a cold climate, Indoor Air, $17: 37-49$.

Li, Z., Chen, W., Deng, S., Lin, Z. (2006). The characteristics of space cooling load and indoor humidity control for residences in the subtropics, Building and Environment, 41: 11371147.

Mudarri, D., Fisk, W.J. (2007). Public health and economic impact of dampness and mold, Indoor Air, 17(3): 226-235.

Osanyintola, O.F., Simonson, C.J. (2006). Moisture buffering capacity of hygroscopic building materials: experimental facilities and energy impact, Energy and Buildings, 38: 12701282.

Pasanen, A.-L., Kasanen, J.-K., Rautiala, S., Ikäheimo, M., Rantamäki, J., Kääriäinen, H., Kalliokoski, P. (2000). Fungal growth and survival in building materials under fluctuating moisture and temperature conditions, International Biodeterioration \& Biodegradation, 46: 117-127.

Padfield, T. (1998). The role of absorbent building materials in moderating changes of relative humidity, Ph.D. thesis, Technical University of Denmark, Copenhagen, Denmark.

Pavlovas, V. (2004). Demand controlled ventilation: A case study for existing Swedish multifamily buildings. Energy and buildings, 26: $1029-1034$.

Ramos, N.M., de Freitas, V.P. (2006). Evaluation strategy of finishing materials contribution to the hygroscopic inertia of a room, Research in Building Physics and Building Engineering, Concordia University, Montreal, Canada, 543-548.

Rode, C., Mendes, N., Grau, K. (2004). Evaluation of moisture buffer effects by performing whole-building simulations, ASHRAE Transactions, 110 (2): 783-794.

Rode, C., Peuhkuri, R., Time, B., Svennberg, K., Ojanen, T. (2007). Moisture buffer value of building materials, Journal of ASTM International, 4(5).

Roels, S., Janssen, H. (2006). A comparison of the Nordtest and Japanese test methods for the moisture buffering performance of building materials, Journal of Building Physics, Vol. 30, p. 137-161.

Sedlbauer, K. (2002). Prediction of mould growth by hygrothermal calculation, Journal of Thermal Envelope and Building Science, 25(4): 321-336.

Simonson. C.J., Salonvaara, M., Ojanen, T. (2004a). Heat and mass transfer between indoor air and a permeable and hygroscopic building envelope : part 1 - Field measurements, Journal of Thermal Envelope and Building Science, 28(1): 63-101.

Simonson, C.J., Salonvaara, M., Ojanen, T. (2004b). Heat and mass transfer between indoor air and a permeable and hygroscopic building envelope : part 2 - Verification and numerical studies, Journal of Thermal Envelope and Building Science, 28(2): 161-185.

Steeman, H.J., T'Joen, C., Willockx, A., De Paepe, M., Janssens, A. (2006). CFD modelling of HAM transport in buildings: boundary conditions, Research in Building Physics and Building Engineering, Concordia University, Montreal, Canada, 535-542.

Stehno, V. (1982). Praktische Berechnung der instationären Luftzustandsänderungen in Aufenthaltsräumen zur Beurteilung der Feuchtigkeitsbelastung der raumbegrenzenden Bauteile. Bauphysik,4: 128-134.

Svennberg, K., Hedegaard, L., Rode, C. (2007). Moisture buffer performance of a fully furnished room, Proceedings of the $9^{\text {th }}$ International Conference on Performance of the Exterior Envelopes of Buildings, Clearwater Beach, Florida, USA, December 2-7.

Thomson, G. (1964). Relative humidity: Variation with temperature in a case containing wood, Conservation, International Institute for Conservation of Historical and Artistic Works 
Postprint: Vereecken E, Roels S, Janssen H, 2011. In situ determination of the moisture buffer potential of room enclosures, Journal of Building Physics, 34(3): 223-246.

doi: $10.1177 / 1744259109358268$

Toftum, J., Fanger, P.O. (1999). Air humidity requirements for human comfort, ASHRAE

Transactions, 105(2):641-647

TRNSYS 16. (2006). A TRaNsient SYstem Simulation program, User Guide Version 16.1. Madison: Solar Energy Lab, University of Wisconsin-Madison.

Vereecken, E. (2008). How important are interior finishing materials to reduce relative humidity variations in indoor spaces, Master Thesis (in Dutch), K.U. Leuven, Belgium.

\section{TABLE CAPTIONS}

1. The dimensions and the beforehand determined $M B V_{1 h}$ and $M B V_{8 h}$ of the hygric elements placed in the test room for the validation of the developed methodology.

2. Comparison of the with Eq. (8) determined $\mathrm{HIR}^{*}$-values $\left(\mathrm{g} /\left(\mathrm{m}^{3} . \% R H\right)\right)$ to the in situ (with EC- and EMPD-model) determined $\mathrm{HIR}^{*}$-values of the test room. The $\mathrm{HIR}_{1 \mathrm{~h}}$ of $0.04 \mathrm{~g} /\left(\mathrm{m}^{3} . \% R \mathrm{H}\right)$ is obtained based on the long term experiment.

\section{FIGURE CAPTIONS}

1. Determination of the $\mathrm{MBV}^{(\prime)}$ of a bookshelf $(1 \mathrm{~m})$ with books.

2. Schematic figure of a) the influence of the $\mathrm{ACH}$ at the $\mathrm{RH}$-increase and $\mathrm{RH}$-decrease, b) the influence of the $\mathrm{HIR}^{*}$-value at the $\mathrm{RH}$-increase and $\mathrm{RH}$-decrease, c) the total $\mathrm{RH}$-increase and decrease in function of the $\mathrm{ACH}$ for a constant $\mathrm{HIR}^{*}$-value.

3. Schematic figure for the determination of the $\mathrm{HIR}^{*}$-value and $\mathrm{ACH}$ : draw the theoretical curves of the total $\mathrm{RH}$-increase and decrease, draw the measured total $\mathrm{RH}$ increase and decrease and look for the curves which intersects the measured $\mathrm{RH}$ increase and decrease at the same HIR*-value and $\mathrm{ACH}$. In this case a HIR*-value of $0.59 \mathrm{~g} /\left(\mathrm{m}^{3} . \% \mathrm{RH}\right)$ is obtained.

4. View of the test set-up in the Vliet-test building

5. Comparison of the measured $\mathrm{RH}$-course in the long term experiment to the with Eq.(8) predicted $\mathrm{RH}$-course and to the with the in situ determined $\mathrm{HIR}_{8 \mathrm{~h}}$-value predicted $\mathrm{RH}$-course.

6. Comparison of the measured $\mathrm{RH}$-course in the short term experiment to the with Eq. (8) predicted $\mathrm{RH}$-course and to the with the in situ determined $\mathrm{HIR}_{1 \mathrm{~h}}$-value predicted $\mathrm{RH}$-course.

7. Comparison of the measured $\mathrm{RH}$-courses to the with the EMPD-model obtained $\mathrm{RH}$ courses for the a) long and b) short term experiment.

8. Inside view of the student room.

9. Comparison of the measured $\mathrm{RH}$-course in the student room to the with the in situ determined $\mathrm{HIR}_{8 \mathrm{~h}}$-value predicted $\mathrm{RH}$-courses: a) EC-model, b) EMPD-model. 
Postprint: Vereecken E, Roels S, Janssen H, 2011. In situ determination of the moisture buffer potential of room enclosures, Journal of Building Physics, 34(3): 223-246.

doi: $10.1177 / 1744259109358268$

TABLE 1

\begin{tabular}{|c|c|c|c|}
\hline Material & $\begin{array}{l}\text { Area ; } \\
\text { length }\end{array}$ & $\mathrm{MBV}_{1 \mathrm{~h}}$ & $\mathrm{MBV}_{8 \mathrm{~h}}$ \\
\hline & $\left(m^{2} ; m\right)$ & $\left(\mathrm{g} /\left(\mathrm{m}^{(2)} . \% \mathrm{RH}\right)\right)$ & $\left(\mathrm{g} /\left(\mathrm{m}^{(2)} . \% \mathrm{RH}\right)\right)$ \\
\hline wood-wool cement board & 0.834 & 1.17 & 3.32 \\
\hline wood-fibre board & 9.375 & 0.36 & 1.15 \\
\hline pile of journals $\left(20 \times 29 \mathrm{~cm}^{2}\right)$ & 0.225 & 0.84 & 2.64 \\
\hline $\begin{array}{c}\text { pile of newspapers } 1 \\
\left(20 \times 29 \mathrm{~cm}^{2}\right)\end{array}$ & 0.180 & 0.91 & 3.23 \\
\hline $\begin{array}{l}\text { pile of newspapers } 2 \\
\left(20 \times 29 \mathrm{~cm}^{2}\right)\end{array}$ & 0.175 & 0.91 & 3.23 \\
\hline pile of books $\left(17.5 \times 25 \mathrm{~cm}^{2}\right)$ & 0.300 & 0.71 & 2.45 \\
\hline books in rack $\left(17.5 \times 25 \mathrm{~cm}^{2}\right)$ & 0.305 & 0.71 & 2.45 \\
\hline
\end{tabular}

\section{TABLE 2}

\begin{tabular}{|l|c|c|c|}
\hline Production scheme & Eq. 9 & In situ (EC-model) & In situ (EMPD-model) \\
\hline Long & 0.51 & 0.59 & 0.40 \\
\hline Short & 0.16 & $0.07(0.04)$ & 0.18 \\
\hline
\end{tabular}


Postprint: Vereecken E, Roels S, Janssen H, 2011. In situ determination of the moisture buffer potential of room enclosures, Journal of Building Physics, 34(3): 223-246.

doi: $10.1177 / 1744259109358268$

FIGURE 1

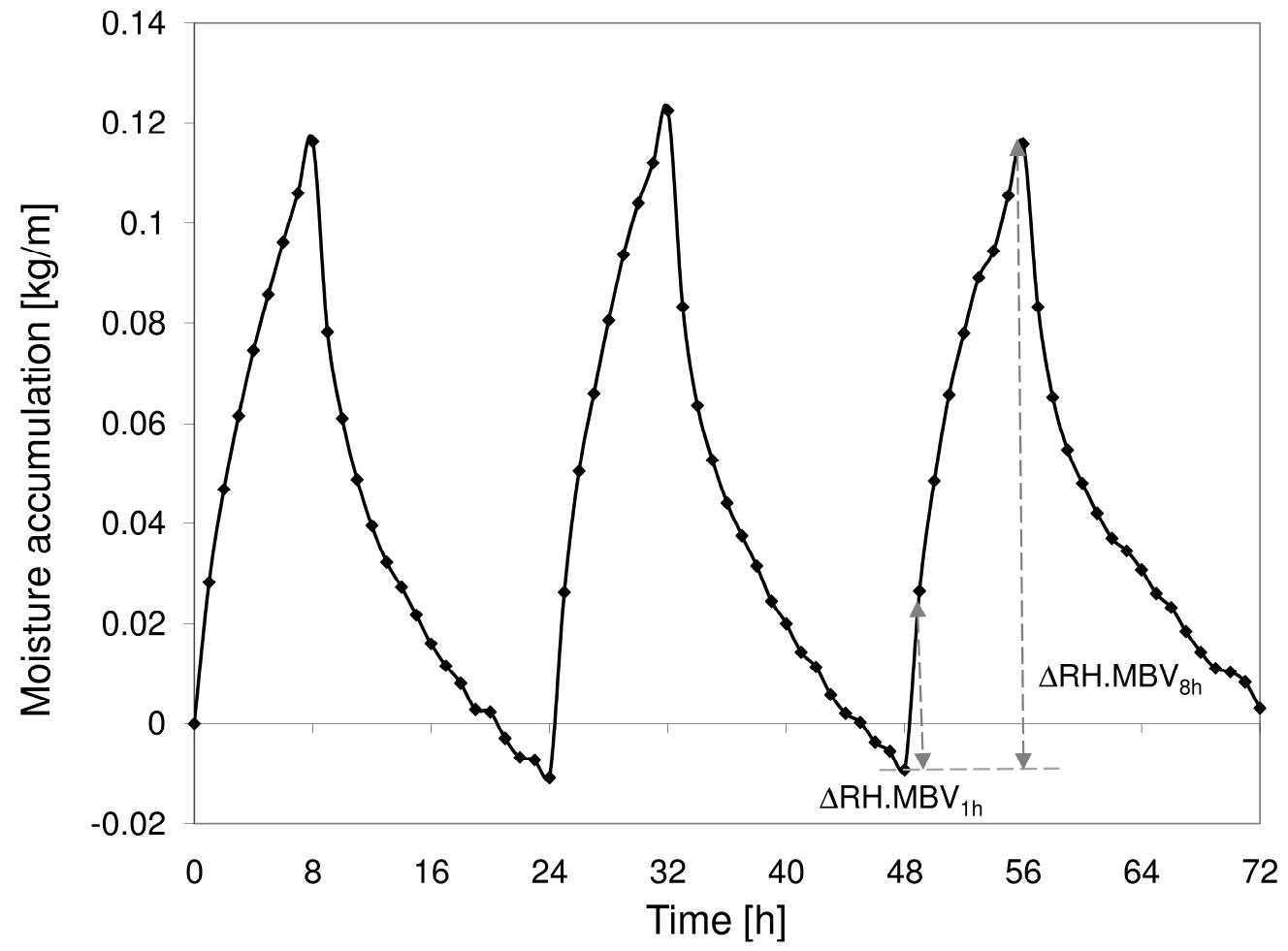


Postprint: Vereecken E, Roels S, Janssen H, 2011. In situ determination of the moisture buffer potential of room enclosures, Journal of Building Physics, 34(3): 223-246.

doi: $10.1177 / 1744259109358268$

FIGURE 2

a)

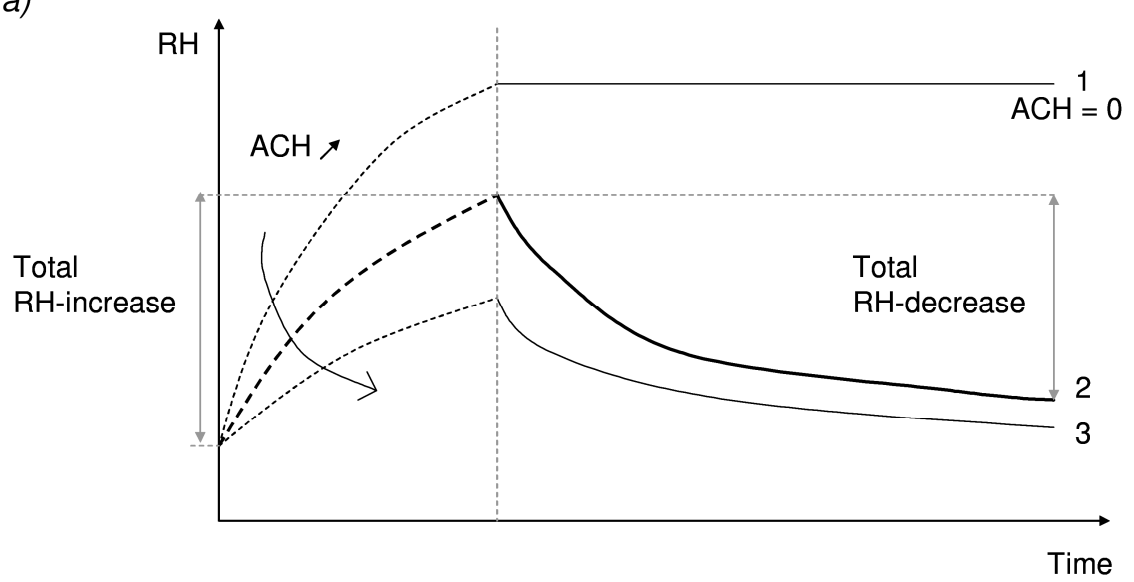

b)

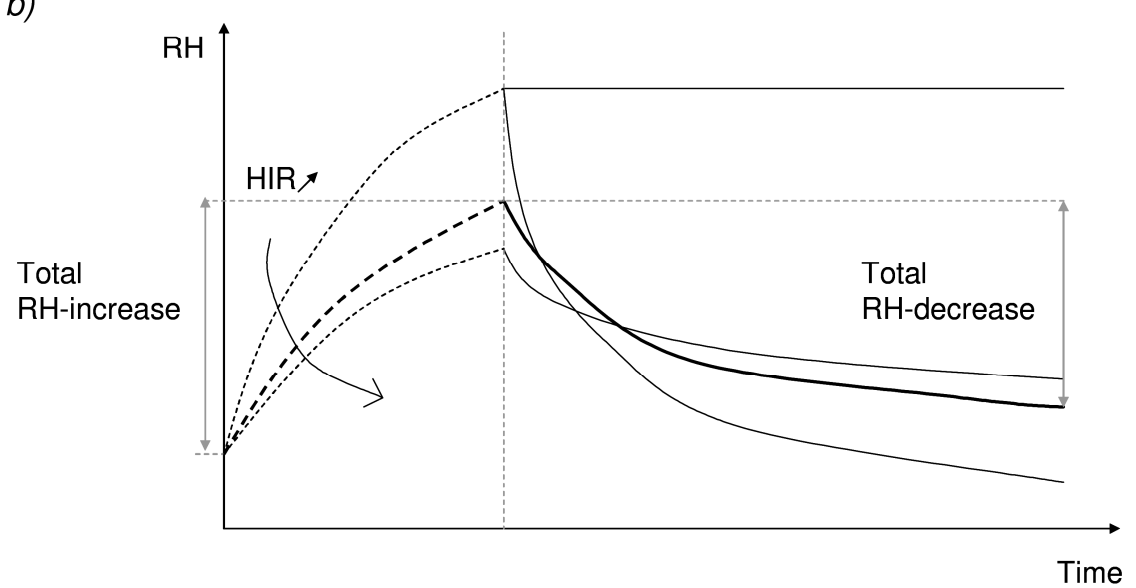

c)

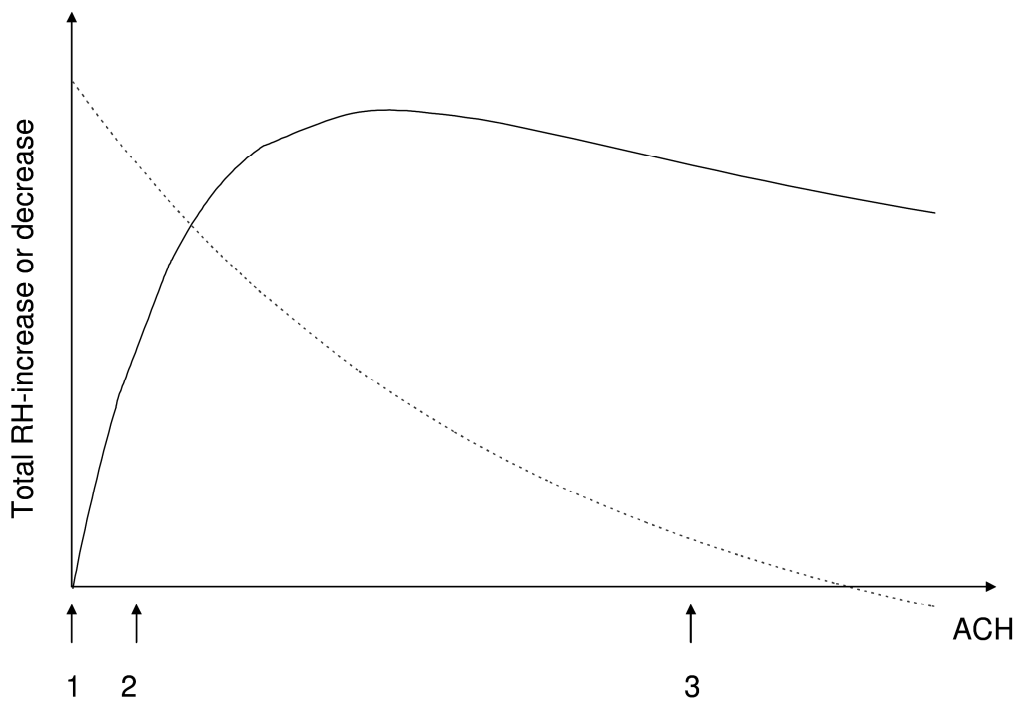


Postprint: Vereecken E, Roels S, Janssen H, 2011. In situ determination of the moisture buffer potential of room enclosures, Journal of Building Physics, 34(3): 223-246.

doi: $10.1177 / 1744259109358268$

\section{FIGURE 3}

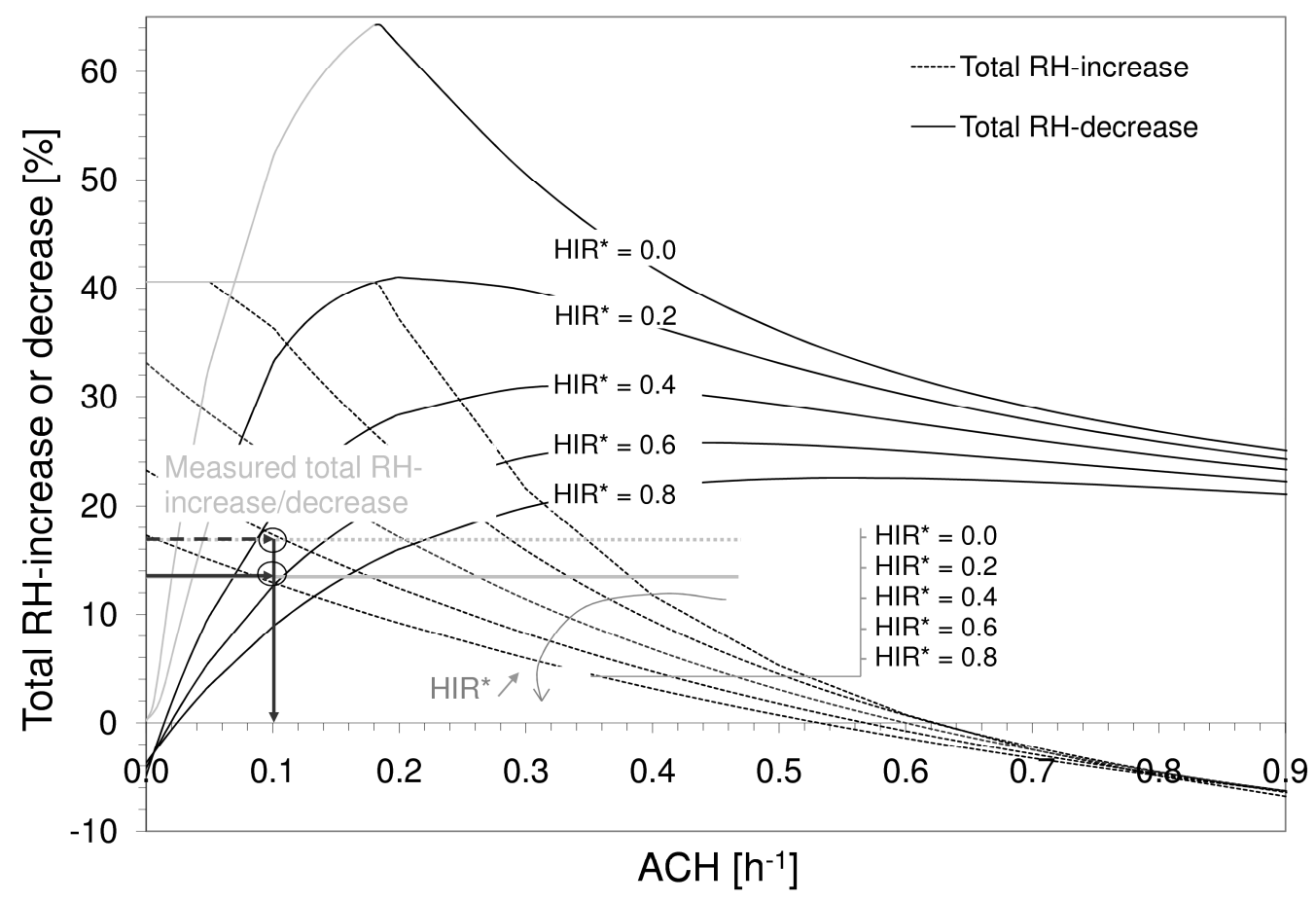

FIGURE 4
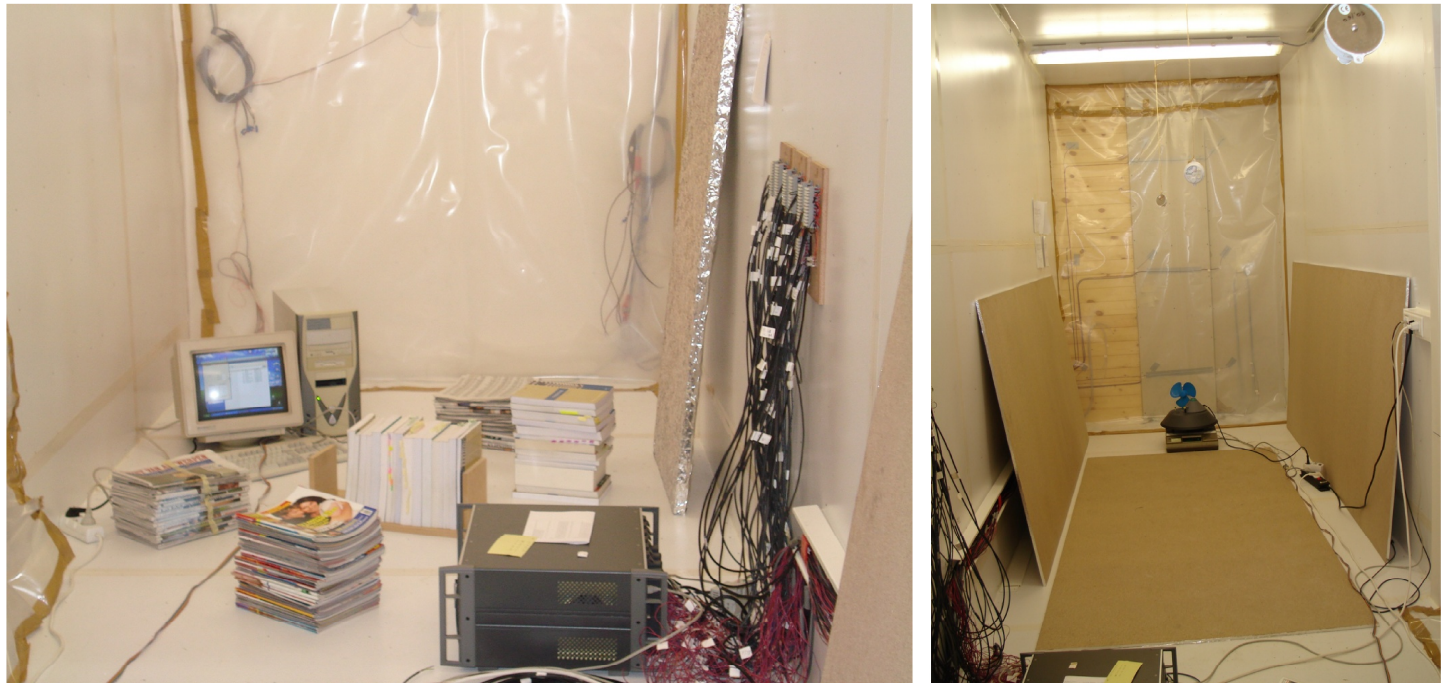
Postprint: Vereecken E, Roels S, Janssen H, 2011. In situ determination of the moisture buffer potential of room enclosures, Journal of Building Physics, 34(3): 223-246.

doi: $10.1177 / 1744259109358268$

FIGURE 5

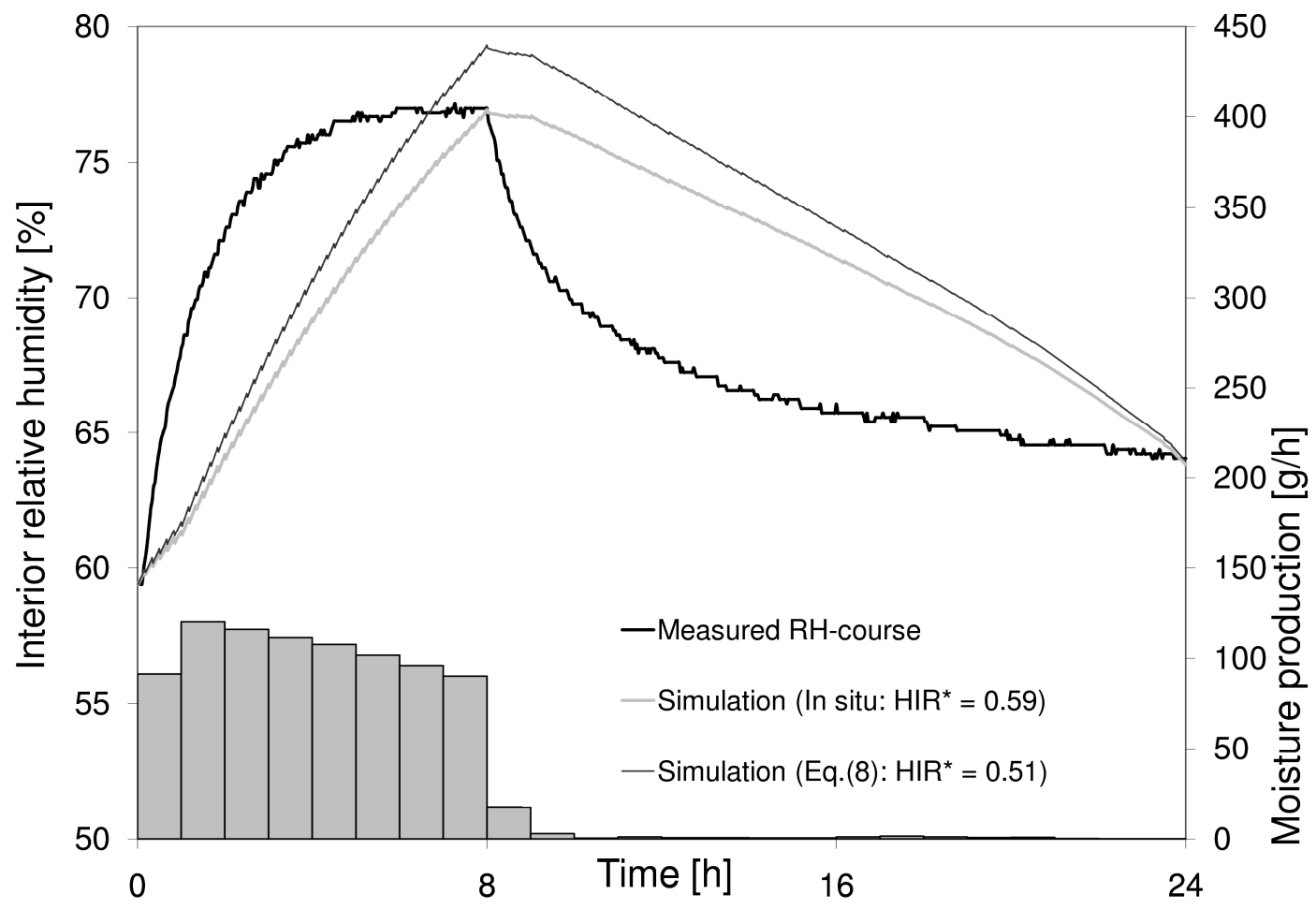


Postprint: Vereecken E, Roels S, Janssen H, 2011. In situ determination of the moisture buffer potential of room enclosures, Journal of Building Physics, 34(3): 223-246.

doi: $10.1177 / 1744259109358268$

\section{FIGURE 6}

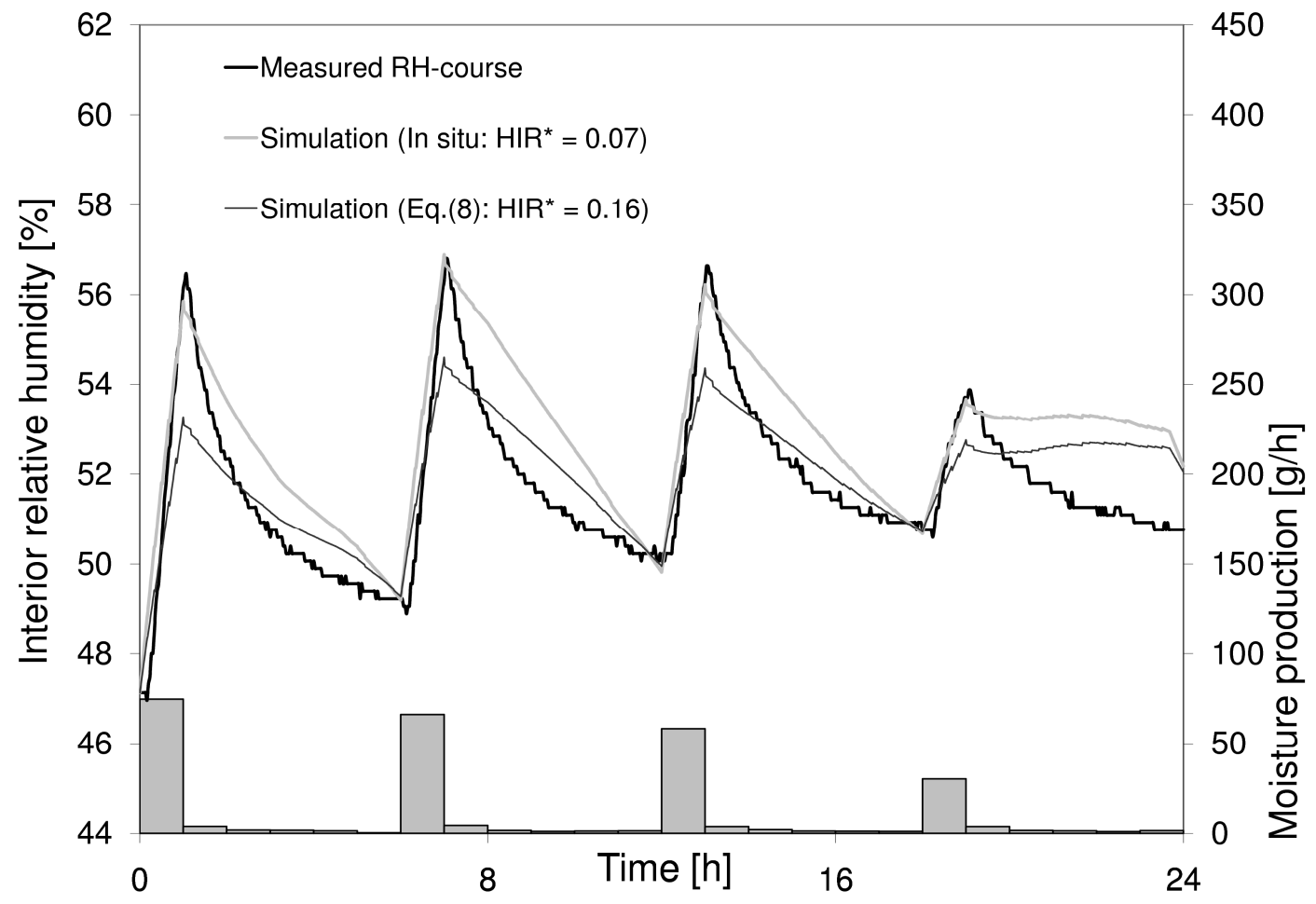


Postprint: Vereecken E, Roels S, Janssen H, 2011. In situ determination of the moisture buffer potential of room enclosures, Journal of Building Physics, 34(3): 223-246.

doi: $10.1177 / 1744259109358268$

\section{FIGURE 7}

a)

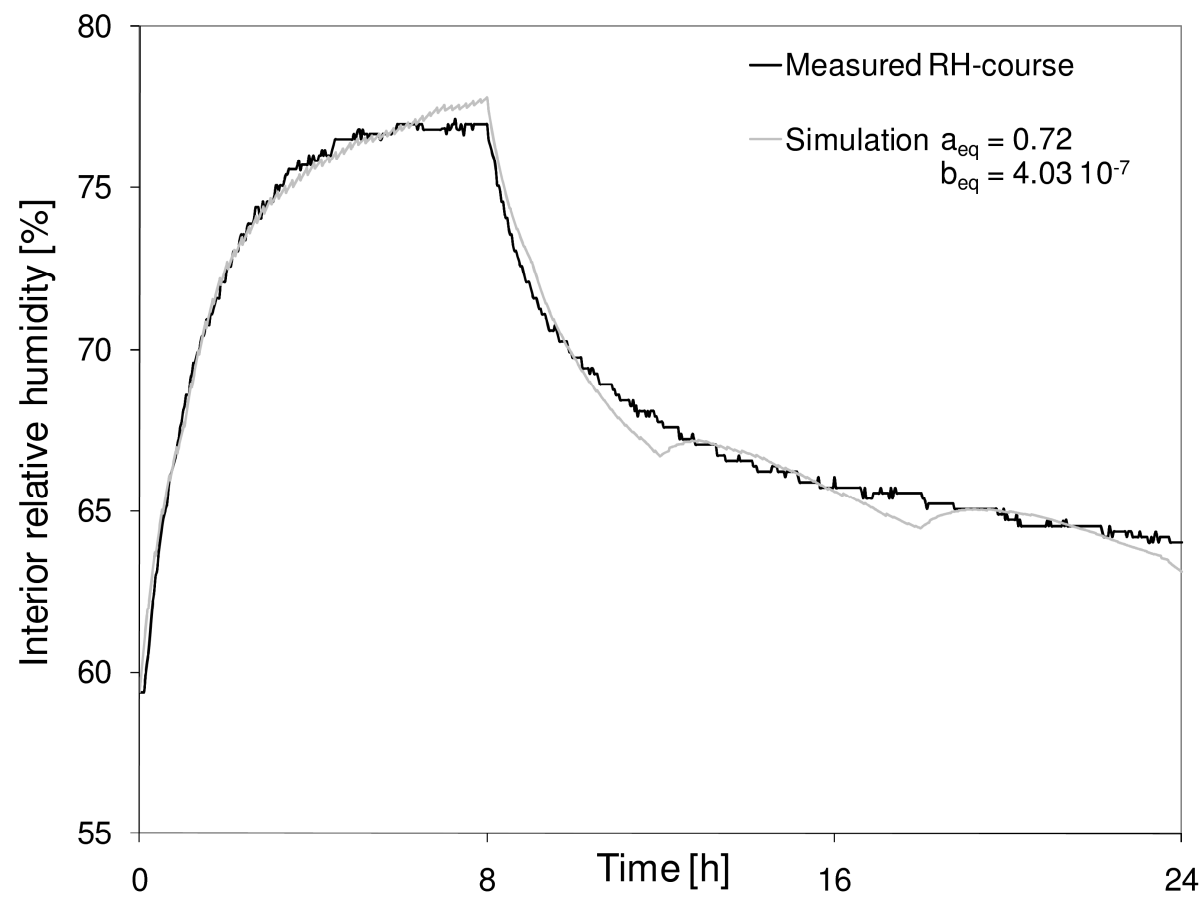

b)

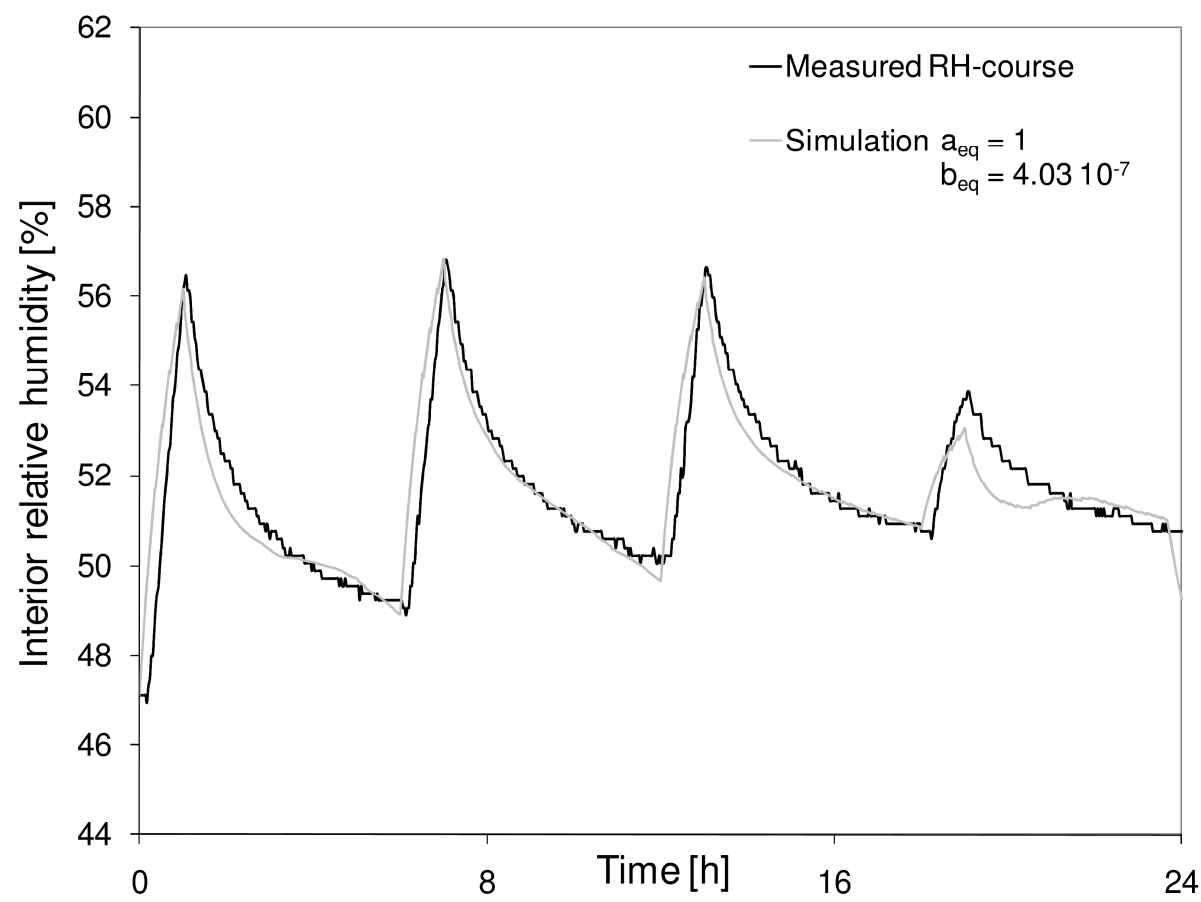


Postprint: Vereecken E, Roels S, Janssen H, 2011. In situ determination of the moisture buffer potential of room enclosures, Journal of Building Physics, 34(3): 223-246.

doi: $10.1177 / 1744259109358268$

\section{FIGURE 8}
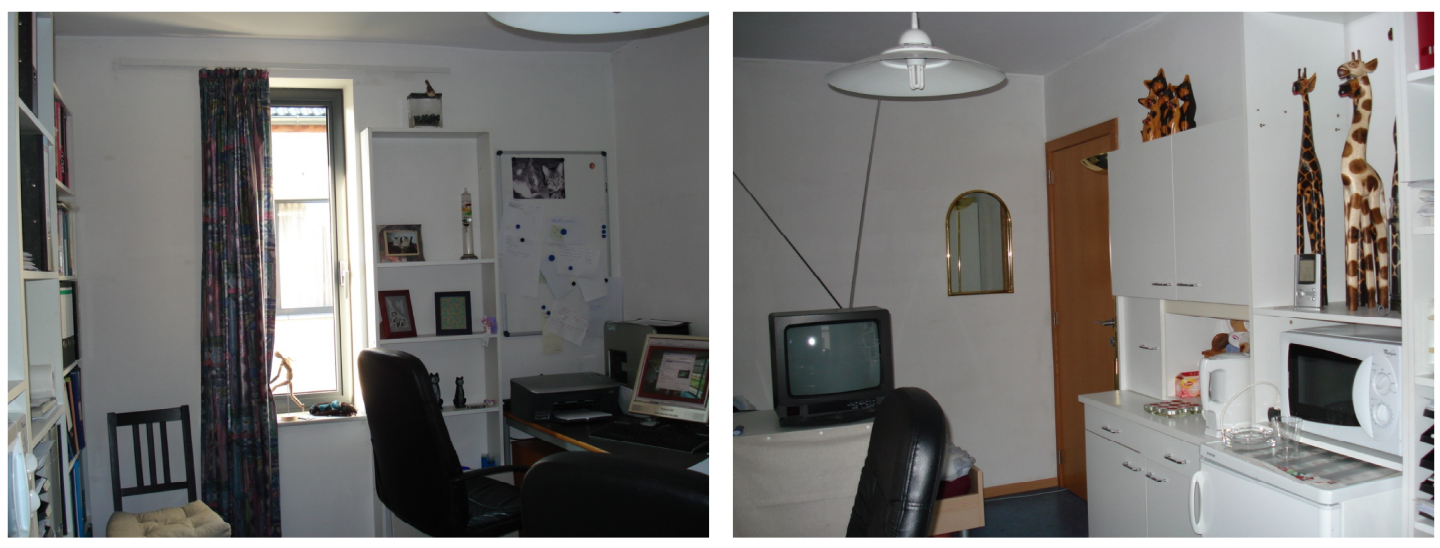
Postprint: Vereecken E, Roels S, Janssen H, 2011. In situ determination of the moisture buffer potential of room enclosures, Journal of Building Physics, 34(3): 223-246.

doi: $10.1177 / 1744259109358268$

\section{FIGURE 9}

a)

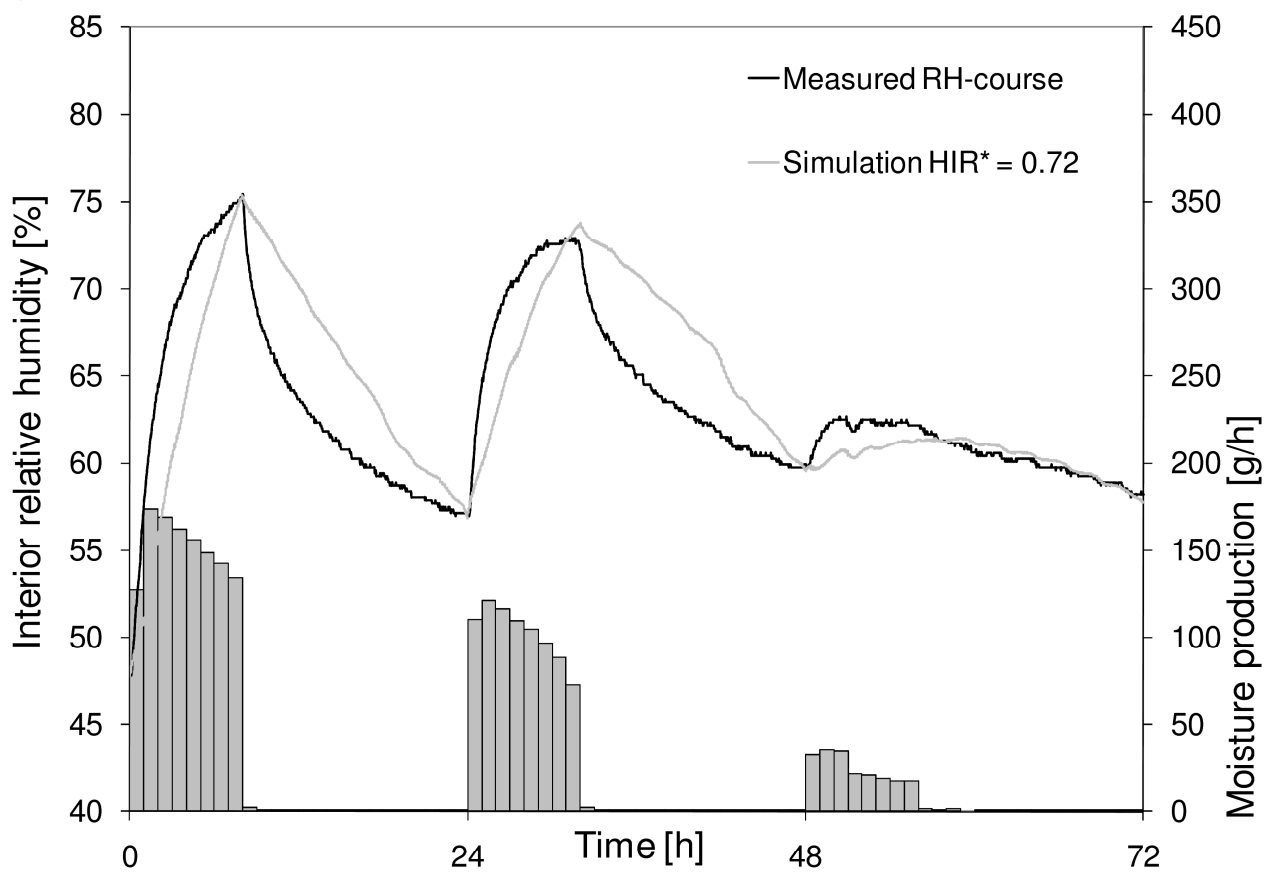

b)

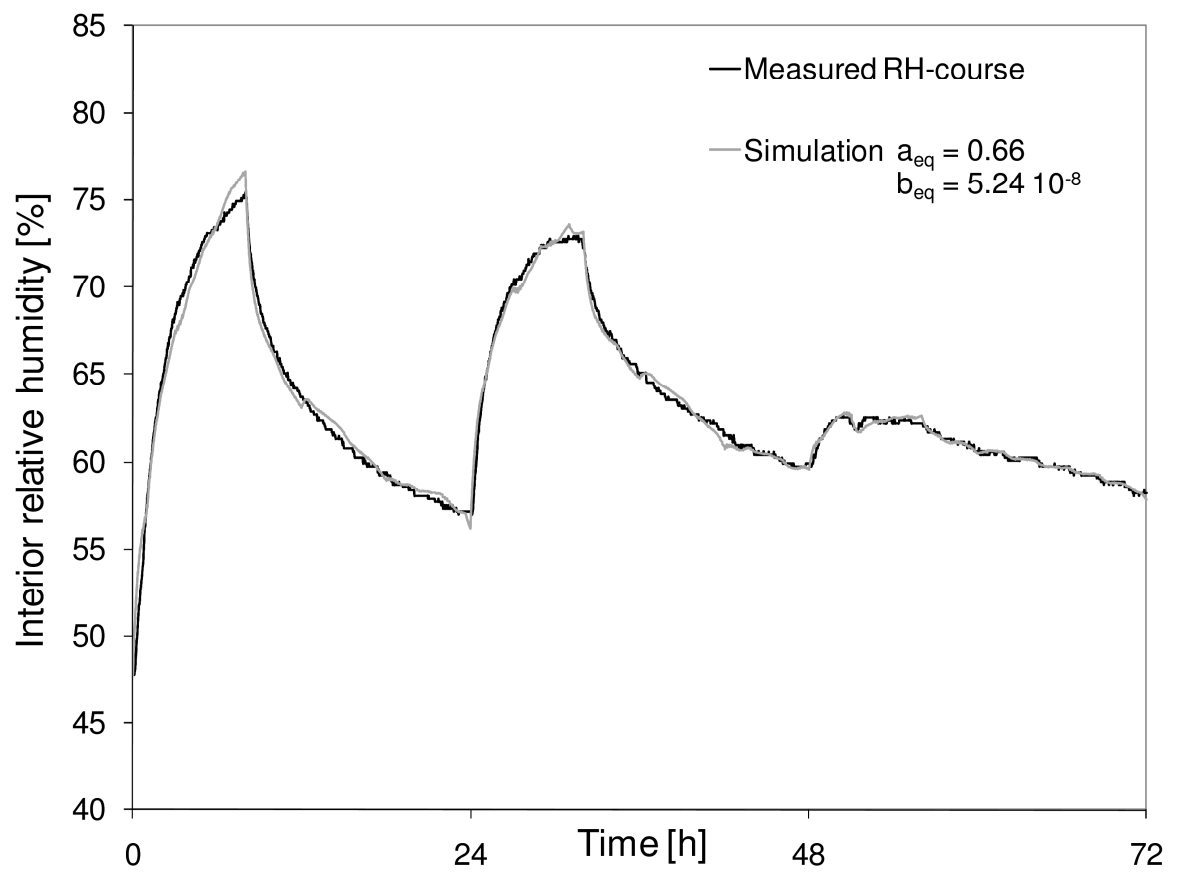

